\title{
The Effect of Kluwih (Artocarpus communis) Fruit Flesh Addition to the Nutrition Content of Mackerel Tuna Fish Abon
}

\author{
Nurlaila Abdullah, Rindam Latief, Februadi Bastian, Nandi K Sukendar, Muspirah Djalal \\ and Melinda Restu Pala'langan
}

Department of Agricultural Technology, Faculty of Agriculture, Hasanuddin University, Indonesia

\begin{abstract}
One of the plants that are easily found in tropical country including Indonesia, but has not been used optimally is Kluwih fruit (Artocarpus communis). In fact, the fiber content in Kluwih is similar to meat that makes it good to be used as abon ingredient. Abon normally made of meat that makes the price generally high. To reduce the prices of abon to be affordable by the middle and lower classes, abon products can be made from vegetable ingredients (such as Kluwih) combined with meat. The research methods consisted of three treatments with different in the amount of Kluwih and Mackerel tuna fish ratio. We concluded that Kluwih fruit could be used as a substitute for meat in Abon making. The Kluwih addition in Fish Abon making affects the nutrition content of the Mackerel tuna abon final product significantly
\end{abstract}

\section{Article History}

Received March 22, 2020

Accepted June 19, 2020

Keyword

Abon,

Mackerel tuna fish, Kluwih.

\section{Introduction}

Indonesia is a tropical country that is overgrown with a variety of biological resources. One of the plants that are easily found in tropical country, including Indonesia but have not been used optimally, is Kluwih fruit (Artocarpus Communis) (1). Kluwih is included in the type of jackfruit (Artocarpus), which is famous for its scientific name, Artocarpus comrnunis, A. altilis or A. insica. Kluwih fruit looks like breadfruit, but Kluwih has rough skin and has seeds, while breadfruit has finer skin and no seeds (2).

Lack of interest to utilizing this fruit, resulting in Kluwih fruit, has a low selling value. Though Kluwi has a high nutritional content, where per 100gram fruit contains 1.5 grams of protein, 0.3 grams of fat, 27.2 grams of carbohydrates, $28 \mathrm{mg}$ of calcium, $32 \mathrm{mg}$ of iron, 0.9 mg of phosphorus, and a number of vitamin A, B, and C (3). In fact, the flesh of the fruit of fruit is considered to have characteristics that resemble meat with a fiber content of $2.3 \%$ so that it can meet the criteria as a good abon raw material.

Abon is defined as dried meat that has been sliced thinly and generally made from beef (4). Abon can also be made from other kinds of meat, such as fish and chicken. The main ingredient of Abon (meat and fish) is what usually makes Abon generally known to be expensive. To reduce abon prices to be affordable by the middle and lower classes, abon products can be made from vegetable ingredients combined with meat (5).

Based on the description above, it is necessary to conduct research on the manufacture of Abon based on Mackerel tuna fish with the addition of Kluwih fruit to see the nutritional content of abon, which is made with a combination of vegetables and animal ingredients. 


\section{Materials and Methods}

\subsection{Seasoning Sauce Making}

All the ingredients such as galangal, lemongrass, onion, garlic, coriander, turmeric, salt, bay leaf, and oil are prepared and sorted. Then these ingredients were cleaned, chopped, and blended. Galangal and lemongrass are squeezed out to avoid astringent to the taste. Blended onion and garlic, then stir-fried with oil. The ingredients were weighed as needed, blended and squeezed galangal and lemongrass 300 gram and 50 gram, respectively. Stirfried onion and garlic 100gram and $75 \mathrm{gram}$, respectively. All ingredients then mixed in a small container. Then, two packages of coconut milk (Kara) diluted using $500 \mathrm{ml}$ of water and added it to the mixed ingredients. Then 20gram turmeric, 30gram coriander, 15gram cumin, 15gram salt, and 10gram pepper were added to the mixed ingredients. Then the mixed ingredient cooked. During the cooking process, the mixed ingredient was continuously stirred until it is cooked well and form seasoning sauce.

\subsection{Mackerel tuna Fish Steaming}

The fish was cleaned and washed, then steamed for about \pm 20 minutes. Fish that have been steamed then drained and cooled. After it is cold, the fish are then shredded.

\subsection{Kluwih Steaming}

Kluwih fruit is peeled and then washed using saltwater with a ratio of salt to water of $20 \mathrm{gram}$ of salt in 1 liter of water. After being washed, the Kluwih is divided into four parts then the Kluwih seeds are separated from the pulp. After cleaning, the flesh of the Kluwih steamed for \pm 20 minutes. Kluwih flesh that has been steamed, then drained and cooled. After it is cold, the Kluwih are then shredded.

\subsection{Abon Making}

The Kluwih fruit and the fish that has been shredded then mixed with $10 \%$ of seasoning sauce. Let it for 10 minutes, then fried. Then the Abon spin for 1 minute.

\subsection{Research Design}

Three treatments were performed in this research called A1, A2, A3 with the following explanation.

A1 : $65 \%$ fish $+25 \%$ Kluwih $+10 \%$ spices sauce

A2 : $45 \%$ fish $+45 \%$ Kluwih $+10 \%$ spices sauce

A3 : $25 \%$ fish $+65 \%$ Kluwih $+10 \%$ spices sauce

\subsection{Observational Parameters}

Observational parameters performed on this research were water content, protein content, fat content, fiber content, and ash content $(6,7)$.

\subsection{Data Analysis}

All parameters were analyzed using analysis of variance (ANOVA) with three replications, and the difference between treatments was analyzed using Duncan test. Software used was Microsoft Excel 2010 and SPSS version 22. 


\section{Results and Discussion}

\subsection{Water Content}

Water content can affect the quality of food so in the processing and storage process it is needed to be reduced. Water content measurement was conducted to understand the maximum water content and the amount of water in a food product (8). Water content measurement is important for a product that needs to be stored in a long period like abon so that the limit of water content for high shelf life products can be understood.

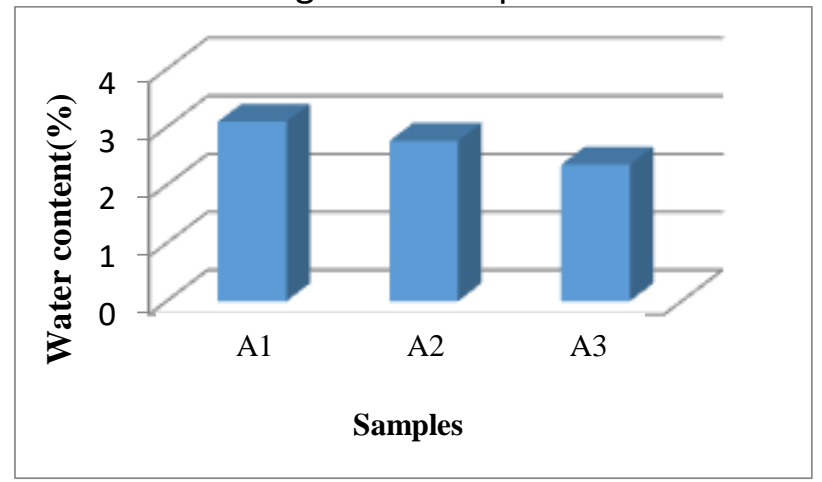

Figure 1. The water content of abon product from mackerel tuna fish and kluwih fruit.

The water content of each treatment ranged between 3.11-2.31\%. Figure 1 shows that the lowest water content can be seen in sample A3 (65\% of Kluwih: $25 \%$ Fish), which was $3.097 \%$, while the highest water content can be seen in sample $A 1$ (25\% Kluwih: $65 \%$ fish), which was $2.353 \%$. Duncan test showed that Kluwih addition to the abon making significantly influenced the water content.

The total water content found in Kluwih fruit is $10 \%$, and in tuna, fish is $69.40 \%$. After processing into abon, a decrease in water content occurs. The water content obtained from each treatment is different where at $65 \%$ fish $+25 \%$ kluwih $+10 \%$ seasoning is $3.097 \%$, at $45 \%$ fish $+45 \%$ kluwih $+10 \%$ seasoning is $2.763 \%$ and at $25 \%$ fish $+65 \%$ Kluwih $+10 \%$ seasoning is $2.33 \%$. The water content obtained in each treatment has met the standards set by Indonesian National Standard (SNI) that is a maximum of $10 \%$. This is in accordance with the Indonesian Industry Standard for Abon No 0368-80, 0368-85 where the water standard for Abon is a maximum of $10 \%$. The factor that plays an important role in reducing water content is by frying. In the frying process, the amount of water in food will evaporate, which will then be filled by the oil used in frying. This is in accordance with Muchtadi's statement (2008) that the composition of fried food will determine the amount of oil absorbed (9). Food with high water content will absorb more oil because empty space is left by the water that evaporates during frying.

\subsection{Fat Content}

Fats are substances that do not dissolve in water that generally comes from plants or animals. Fat is an important food substance to maintain health. In addition, fat is also an effective source of energy, which is very important for the body (6). Measuring for fat content aims to determine the fat content in Abon products because in the process of making Abon, some of the ingredients used are sources of fat, namely coconut milk and cooking oil. 


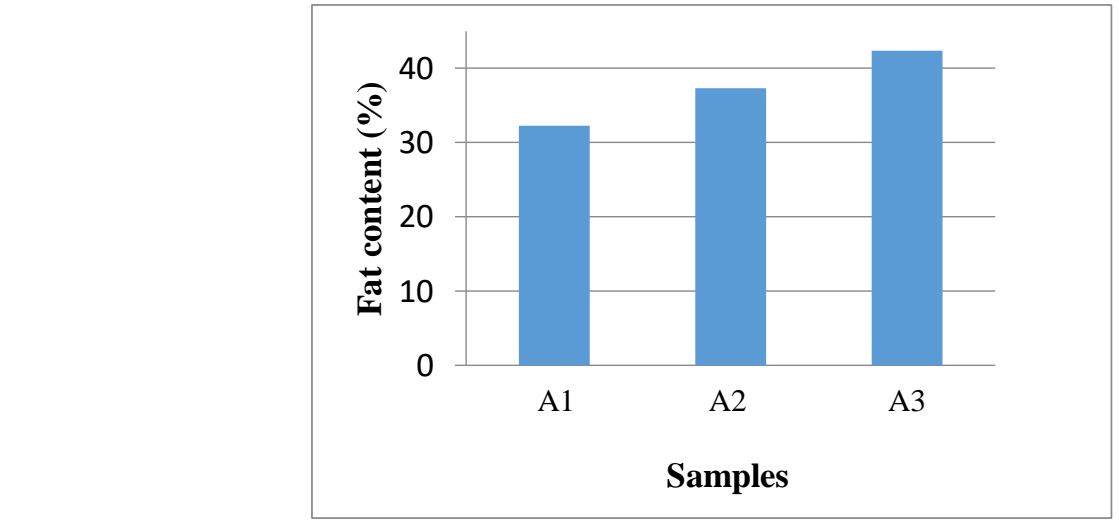

Figure 2. The fat content of abon product from mackerel tuna fish and kluwih fruit.

Fat content obtained in each treatment ranged from 32.33 to $42.39 \%$. Figure 2 shows that the lowest fat content was obtained in the treatment of $65 \%$ fish $+25 \%$ Kluwih $+10 \%$ seasoning, which was $32.33 \%$, while the highest fat content is in the treatment of $25 \%$ fish + $65 \%$ Kluwih $+10 \%$ seasoning as much as $42.39 \%$. Based on the results of the analysis of variance shows that the treatments in making Abon has a very significant effect at the level of $5 \%$ and $1 \%$ so that further testing is carried out. Based on Duncan's test results showed that the difference in the addition of Kluwih had a very significant effect on the fat content of Abon products.

Total fat content in Kluwih fruit is $5.6 \%$, and in tuna is $1.50 \%$. After processing into Abon, the fat content increases. The fat content obtained from each treatment is as follows: $25 \%$ fish $+65 \%$ Kluwih $+10 \%$ seasoning is $32.33 \%$, in $45 \%$ fish $+45 \%$ Kluwih $+10 \%$ seasoning is $37.34 \%$ and at $25 \%$ fish $+65 \%$ Kluwih $+10 \%$ seasoning is $42.39 \%$. Based on the results obtained, the fat content from each treatment did not meet the SNI standard, where the fat content of the SNI standard on Abon products was a maximum of $30 \%$. This is could be because during frying process, there is a high oil absorption, and the pressing process and the duration of oil removal ( 1 minute) are not optimal so that a lot of oil is still bound in the final product. Therefore, to get shredded fat that meets the standards, a longer pressing time is needed when using a spinner. This is thought to be caused by several factors, including the higher levels of fiber material, the more absorbing oil during the frying process. In the frying process, water will evaporate and then be replaced by the oil used. This is in line with Ketaren's (1986) statement that during the frying process some of the oil enters the food and fills the empty space that was originally filled with water (10). Absorption of oil in fish when frying is about $10 \%-20 \%$. Another influential factor is the shape of Abon, which was shredded so that the surface of the material becomes wider, which facilitates oil absorption. This is in accordance with Muchtadi's statement (2008) that the more surface area of fried food is, the more oil will be absorbed (9). In addition, the use of coconut milk in making Abon is also very influential in Abon fat content. Aside from functioning as a savory taste giver, coconut milk will also increase Abon fat levels. This is in accordance with the statement of Sudarmadji (1997), that coconut milk is an emulsion of fat in water that will give a savory taste to food because it contains high levels of fat (6). 


\subsection{Protein Content}

Protein is a large organic compound containing carbon atoms, hydrogen, oxygen, and nitrogen. Some of them contain sulfur, phosphorus, iron, or other minerals (Harris, 1989). Protein analysis aims to determine the amount of protein in Abon. Heating is expected to break certain bonds so that it can cause protein denaturation and increase digestibility, but heating will also cause a decrease in protein levels.

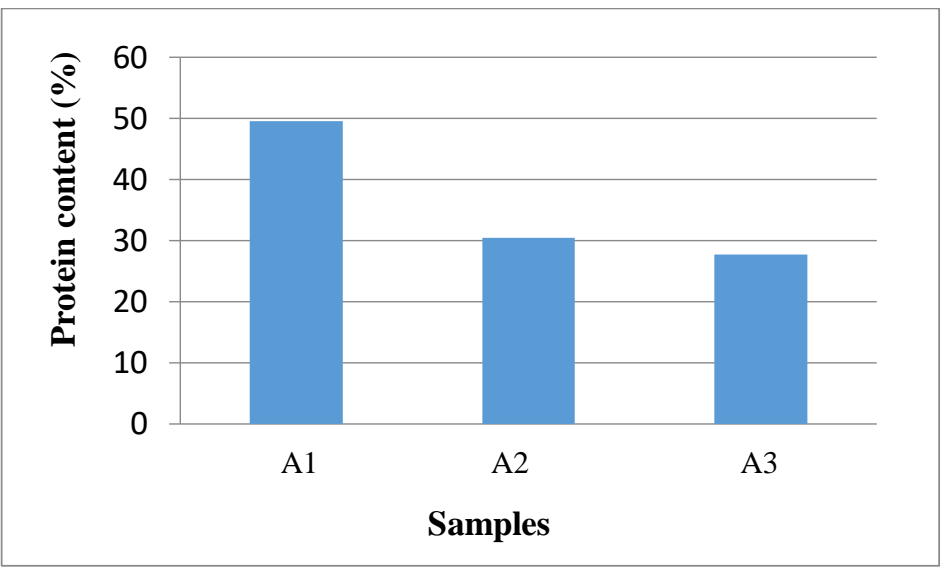

Figure 3. The protein content of abon product from mackerel tuna fish and kluwih fruit.

Protein levels obtained in Abon products ranged from 49.57-27.723\%. Figure 3 shows that the lowest protein content in the treatment of $25 \%$ fish $+65 \%$ Kluwih $+10 \%$ seasoning is $27.733 \%$, while the highest protein content in the treatment of $65 \%$ fish $+25 \%$ Kluwih + $10 \%$ seasoning, which is $49.7 \%$. The results of the analysis of variance showed that the treatment given had a very significant effect on the level of $5 \%$ and $1 \%$ so that further tests were carried out. Duncan's test results showed that the addition of Kluwih had a very significant effect on the protein content of the final product.

The total protein in Kluwih fruit is $8.8 \%$, and in tuna is $25.00 \%$. In the final product, an increase in protein content occurs. Protein content obtained from each treatment that is at $65 \%$ tuna $+25 \%$ Kluwih $+10 \%$ seasoning is as much as $49.57 \%$, in the treatment of $45 \%$ tuna $+45 \%$ Kluwih $+10 \%$ seasoning is $30.47 \%$ and at the treatment of $25 \%$ tuna $+65 \%$ kluwih + $10 \%$ seasoning is as much as $27.72 \%$. Abon protein levels according to SNI maximum of $20 \%$. The protein content is also influenced by the amount of fish used, to get high protein values, one must use a lot of fish too. This is in accordance with the statement of the Department of Industry (1995) that the protein content of Abon can be used as an indication of how much meat is used (11). Low Abon protein levels below $15 \%$ indicate the possibility of using meat that is less than it should or replacing other ingredients such as jackfruit and Kluwih. In addition, the protein in Abon is thought to be influenced by the addition of coconut milk. Coconut milk is not only composed of water and fat but also consists of protein. This is in accordance with the statement of Sudarmadji (1997) that coconut milk contains about $54 \%$, $35 \%$ fat, and $\pm 4 \%$ protein (6).

\subsection{Ash Content}

Ash content or mineral content is the residue that remains if a food sample is completely burned in a furnace. Ash content describes the number of unburnt minerals that become volatile substances. Ash content also determines the presence or absence of 
mineral substances in food. The mineral content is needed in small amounts in the body's work processes. Ash content in food shows the amount of inorganic material left after organic matter has been destroyed (12).

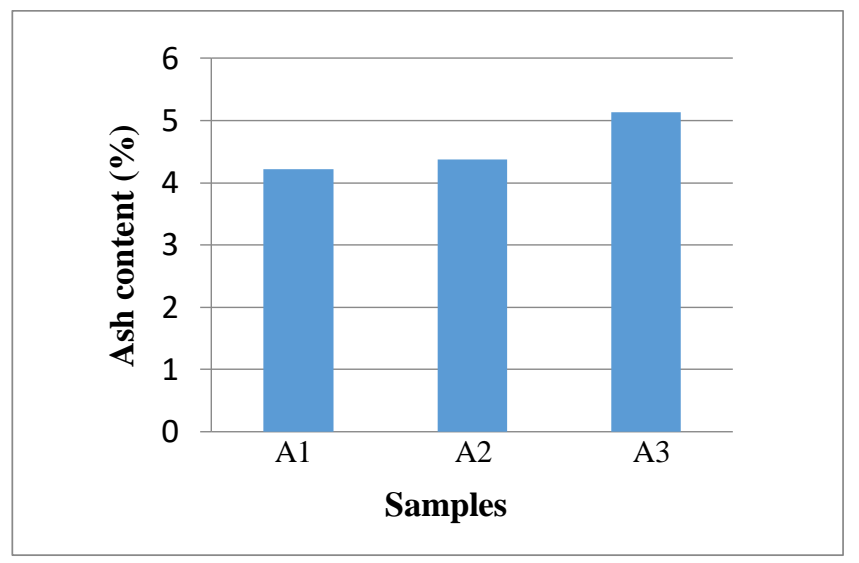

Figure 4. The ash content of abon product from mackerel tuna fish and kluwih fruit.

Ash content obtained in Abon products ranged from 4.21-5.13\%. Figure 4 shows that the lowest ash content in the treatment of $65 \%$ fish: $25 \%$ Kluwih i.e. $4.21 \%$. While the highest ash content was obtained in the treatment of $25 \%$ fish: $65 \%$ Kluwih i.e. $5.13 \%$. The results of the analysis of variance showed that the treatment in the making Abon had a very significant effect at the level of $5 \%$ and $1 \%$ so that further tests were carried out. Duncan's test results showed that the difference in the addition of Kluwih in each treatment had a very significant effect on ash content in the Abon produced.

The ash content obtained from each treatment was as follows: $65 \%$ of tuna $+25 \%$ Kluwih $+10 \%$ seasoning was $4.21 \%$, in the treatment of $45 \%$ tuna $+45 \%$ Kluwih $+10 \%$ seasoning was $4.37 \%$ and at the treatment of $25 \%$ fish $+65 \%$ Kluwih $+10 \%$ seasoning was $5.13 \%$. Ash content in Abon products still meets the standard for products, which is $7 \%$. The low value of the ash content is due to the low minerals contained in Abon. According to Andarwulan et al. (2011), the effect of processing on ingredients can affect the availability of minerals for the body (13). The use of water in the process of washing, soaking, and boiling can reduce the availability of minerals

\subsection{Fiber Content}

Fiber is a residue from food or agricultural products after being treated with boiling acid or alkali. Components of the fiber consist of cellulose, pentose, lignin, and other components. Components of fiber do not have nutritional value, but the fiber is very important for digestion. 


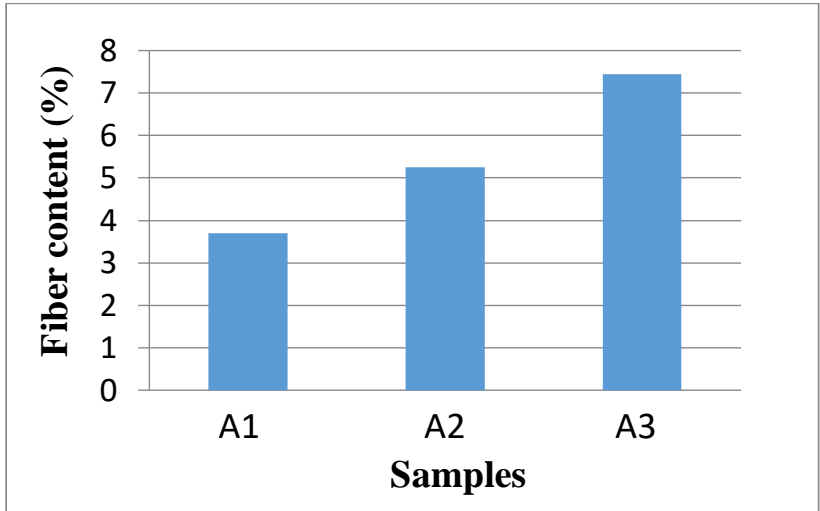

Figure 5. The fiber content of abon product from mackerel tuna fish and kluwih fruit.

Fiber content obtained in Abon products ranged from 3.70-7.44\%. Figure 5 shows that the lowest fiber content was obtained in the treatment of $65 \%$ fish: $25 \%$ Kluwih i.e. $3.70 \%$. While the highest fiber content was obtained in the treatment of $25 \%$ fish: $65 \%$ Kluwih i.e. 7.44\%. The results of the analysis of variance showed that the treatment in the making Abon had a very significant effect at the level of $5 \%$ and $1 \%$ so that further tests were carried out. Duncan's test results show that the difference in the addition of Kluwih in each treatment has a very significant effect on the fiber content of the final product.

The total fiber content in Kluwih fruit is $2.3 \%$, which has fiber content that is almost the same as meat. The fiber content obtained from each treatment is as follows; $65 \%$ tuna + $25 \%$ Kluwih $+10 \%$ seasoning is $3.7 \%$, $45 \%$ tuna $+45 \%$ Kluwih $+10 \%$ seasoning is $5.25 \%$ and $25 \%$ tuna $+65 \%$ Kluwih $+10 \%$ seasoning is $7.44 \%$. From the analysis results obtained, the fiber content obtained in each treatment is greater than the standard fiber content for Shredded set by the National Standards Agency, which is a maximum of $1.04 \%$ (11). The high food fiber produced is thought to be due to the raw materials used, namely Kluwih fruit and fish, which have high fiber content.

\section{Conclusions}

We concluded that Kluwih fruit could be used as a substitute for meat in Abon making. The Kluwih addition in Fish Abon making affects the the nutrition content of abon final product.

\section{References}

1. Pitojo IS. Budi Daya Keluwih. Yogyakarta: Kanisius; 2005.

2. Novary EW. Penanganan dan Pengolahan Sayuran Segar. Jakarta: Penebar Swadaya; 1997.

3. Suryaningsih W. Pengaruh Tingkat Penambahan Nangka Muda dan Kluwih dalam Pembuatan Dendeng Sapi terhadap Mutu Produk. Politeknik Pertanian Universitas Jember; 1993.

4. Astawan MW, Astawan M. Teknologi Pengolahan Pangan Hewani Tepat Guna. Jakarta: Akademika Pressindo; 2006.

5. $\quad$ Fachruddin L. Membuat Aneka Abon. Yogyakarta: Kanisius; 1997.

6. Sudarmaji, Haryono, Suhardi. Analisis Bahan Makanan dan Pertanian. Yogyakarta: Penerbit Liberty; 1997.

7. Apriyantono A, Fardiaz D, Puspitasari NL. Analisis Pangan. Bogor: IPB Press; 1989. 
8. Suprapti. Teknologi Pengolahan Pangan. Yogyakarta: Kanisius; 2003.

9. Muchtadi TR. Teknologi Proses Pengolahan Pangan. Institut Pertanian Bogor; 2008.

10. Ketaren S. Pengantar teknologi minyak dan lemak pangan. Jakarta: UI Press; 1986.

11. Badan Standardisasi Nasional. Standar mutu abon SNI 01-3707-1995. Badan Standardisasi Nasional. 1995.

12. Miratis ST, Sulistiyati TD, Suprayitno HE. Pengaruh Suhu Pengukusan Terhadap Kandungan Gizi Dan Organoleptik Abon Ikan Gabus (Ophiocephalus Striatus). J Mhs Teknol Has Perikan. 2013;1(1):33-45.

13. Andarwulan N, Kusnandar F, Herawati D. Analisis Pangan. Jakarta: Dian Rakyat; 2011. 